Prepared for the U.S. Department of Energy under Contract DE-AC05-76RL01830

\title{
Cost-Effectiveness and Impact Analysis of Adoption of Standard 90.1-2007 for New York State
}

K Gowri

M Halverson

R Bartlett

June 2009

Pacific Northwest

NATIONAL LABORATORY

Proudly Operated by Battelle Since 1965 


\title{
DISCLAIMER
}

This report was prepared as an account of work sponsored by an agency of the United States Government. Neither the United States Government nor any agency thereof, nor Battelle Memorial Institute, nor any of their employees, makes any warranty, express or implied, or assumes any legal liability or responsibility for the accuracy, completeness, or usefulness of any information, apparatus, product, or process disclosed, or represents that its use would not infringe privately owned rights. Reference herein to any specific commercial product, process, or service by trade name, trademark, manufacturer, or otherwise does not necessarily constitute or imply its endorsement, recommendation, or favoring by the United States Government or any agency thereof, or Battelle Memorial Institute. The views and opinions of authors expressed herein do not necessarily state or reflect those of the United States Government or any agency thereof.

\author{
PACIFIC NORTHWEST NATIONAL LABORATORY \\ operated by \\ BATTELLE \\ for the \\ UNITED STATES DEPARTMENT OF ENERGY \\ under Contract DE-AC05-76RL01830
}

Printed in the United States of America

Available to DOE and DOE contractors from the

Office of Scientific and Technical Information,

P.O. Box 62, Oak Ridge, TN 37831-0062;

ph: (865) 576-8401

fax: $(865) 576-5728$

email: reports@adonis.osti.gov

\footnotetext{
Available to the public from the National Technical Information Service, U.S. Department of Commerce, 5285 Port Royal Rd., Springfield, VA 22161 ph: (800) 553-6847 fax: $(703) 605-6900$

email: orders@ntis.fedworld.gov

online ordering: http://www.ntis.gov/ordering.htm
}

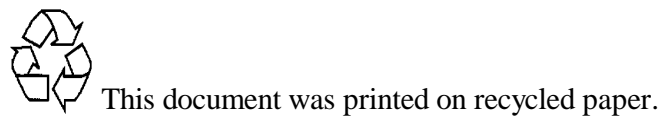




\section{Cost-Effectiveness and Impact Analysis of Adoption of Standard 90.1-2007 for New York State}

K Gowri

M Halverson

R Bartlett

June 2009

Prepared for the U.S. Department of Energy under Contract DE-AC05-76RL01830

Pacific Northwest National Laboratory

Richland, Washington 99352 


\title{
Cost-Effectiveness and Impact Analysis of Adoption of Standard 90.1-2007 for New York State
}

\author{
Krishnan Gowri, Mark Halverson, and Rosemarie Bartlett \\ Pacific Northwest National Laboratory
}

June 25, 2009

\section{Summary:}

This analysis indicates that the adoption of Standard 90.1-2007 is cost-effective under New York's requirements for all buildings in New York.

New York State Calculated Paybacks

\begin{tabular}{|l|l|l|l|}
\hline Building Prototype & $\begin{array}{l}\text { Climate Zone 4A - } \\
\text { New York City }\end{array}$ & $\begin{array}{l}\text { Climate Zone 5A - } \\
\text { Albany }\end{array}$ & $\begin{array}{l}\text { Climate Zone 6A - } \\
\text { Binghamton }\end{array}$ \\
\hline Nonresidential & 8 & 4 & 4 \\
\hline Residential & 10 & 8 & 8 \\
\hline Semiheated & 0 (no change) & 0 (no change) & 0 (no change) \\
\hline
\end{tabular}

\section{Background:}

New York State has requested that BECP provide an analysis of the impacts of adoption of ANSI/ASHRAE/IESNA Standard 90.1-2007. New York State is unique among states in requiring a ten-year payback for energy code measures. BECP has based this analysis on the results of a nationwide, state-by-state code comparison for DOE. The baseline assumptions for the state-by-state code comparison include:

1) The analysis will be based on three building types:

a. medium office (representative of nonresidential construction)

b. mid-rise apartment (representative of residential construction)

c. warehouse (representative of semiheated construction)

2) The analysis will be conducted in one location in each climate zone found in the state (using climate zones defined in Standard 90.1-2007).

3) If a state adopts a version of the IECC, DOE will use the commercial requirements of the IECC version as the baseline requirements for nonresidential and high-rise residential construction.

4) If a state adopts a version of the IECC, DOE will use the semiheated requirements of the ASHRAE reference standard for the IECC version. Thus, for states that adopt the 2003 IECC, DOE will assume the semiheated building is built to the requirements of ANSI/ASHRAE/IESNA Standard 90.1-2001. 
The implications for New York State are as follows:

1) The New York State Energy Conservation Code (NYSECC) is currently based on the 2003 IECC.

2) New York has also updated the ASHRAE reference standard to the 2003 IECC to ANSI/ASHRAE/IESNA Standard 90.1-2004.

3) DOE will use the requirements found in the 2003 IECC for nonresidential and residential construction.

4) DOE will use the requirements found in Standard 90.1-2004 for semiheated construction.

\section{Energy Impact Analysis}

New York State includes three climate zones - 4A, 5A, and 6A. DOE has selected the following cities to represent each zone:

$\begin{array}{ll}\text { Zone 4A } & \text { New York City } \\ \text { Zone 5A } & \text { Albany } \\ \text { Zone 6A } & \text { Binghamton }\end{array}$

The primary difference between current IECC $2003^{1}$ requirements and 90.1-2007 requirements for New York, represented in the analysis are:

(i) Opaque envelope requirements for exterior walls, roof, slab (as shown in Table 1, representing steel frame wall and insulation entirely above deck roof requirements for residential and nonresidential buildings, metal building walls and roof in semiheated buildings)

(ii) Fenestration requirements (as shown in Table 1)

(iii) HVAC equipment efficiencies effective as of 1/23/2006 (includes NAECA covered equipment)

\footnotetext{
${ }^{1}$ For the semiheated portion of the warehouse, the semiheated requirements in ASHRAE Standard 90.1-2001, the reference standard to the 2003 IECC, were utilized as it is believed that this is how a building of this type would typically comply with the 2003 IECC.
} 
Table 1: Comparison of Envelope Requirements (U-factors in Btu/hr.ft $\left.{ }^{2} .^{\circ} \mathbf{F}\right)$

\begin{tabular}{|c|c|c|c|c|c|c|}
\hline & \multicolumn{2}{|c|}{ Climate Zone 4A } & \multicolumn{2}{|c|}{ Climate Zone 5A } & \multicolumn{2}{|c|}{ Climate Zone 6A } \\
\hline & IECC 2003 & $90.1-2007$ & IECC 2003 & $90.1-2007$ & IECC 2003 & $90.1-2007$ \\
\hline Nonresidential & & & & & & \\
\hline Exterior Wall & 0.101 & 0.064 & 0.079 & 0.064 & 0.076 & 0.064 \\
\hline Roof & 0.063 & 0.048 & 0.054 & 0.048 & 0.053 & 0.048 \\
\hline Slab & NR & NR & NR & NR & NR & $\mathrm{R}-10 / 2 \mathrm{ft}$. \\
\hline Window* & $0.57(0.39)$ & $0.52(0.40)$ & $0.57(0.39)$ & $0.48(0.40)$ & $0.57(0.39)$ & $0.48(0.40)$ \\
\hline Residential & & & & & & \\
\hline Exterior Wall & 0.101 & 0.064 & 0.079 & 0.064 & 0.076 & 0.064 \\
\hline Roof & 0.063 & 0.048 & 0.054 & 0.048 & 0.053 & 0.048 \\
\hline Slab & NR & $\mathrm{R}-10 / 2 \mathrm{ft}$ & NR & $\mathrm{R}-10 / 2 \mathrm{ft}$ & NR & R-15/2ft. \\
\hline Window* & $0.62(0.39)$ & $0.52(0.40)$ & $0.62(0.39)$ & $0.48(0.40)$ & $0.62(0.39)$ & $0.48(0.40)$ \\
\hline Semiheated & & & & & & \\
\hline Exterior Wall & 0.113 & 0.113 & 0.113 & 0.113 & 0.113 & 0.113 \\
\hline Roof & 0.065 & 0.065 & 0.065 & 0.065 & 0.065 & 0.065 \\
\hline Slab & NR & NR & NR & NR & NR & NR \\
\hline
\end{tabular}

- Window SHGC shown in parantheses next to the U-factor

New York state-wide average energy savings are estimated based on the requirements for three representative locations for Climate Zones 4A (New York City), 5A (Albany) and 6A (Binghamton). Table 2 shows a summary of average energy use intensities and percentage savings that can be achieved with the adoption of 90.1-2007. Cost savings shown in Table 2 are based on national average fuel prices and not New York State natural gas and electricity prices. New York State fuel prices will be used in the cost-effectiveness portion of this analysis.

Tables A-1 to A-3 in Appendix A present a high level summary of building models used in energy analysis. The energy cost savings are calculated based on a national average fuel price used by the ASHRAE 90.1 Envelope Subcommittee (Electricity: \$ 0.0939/kWh; Natural gas: \$1.2201/therm).

Based on the analysis, New York State can expect to realize state average energy savings of 6\% and cost savings of $4.5 \%$ assuming all new building construction is equally represented by the three prototypes and the climate zones used in the analysis. 
Table 2: New York Energy End Use and Percentage Savings

\begin{tabular}{|c|c|c|c|c|c|c|c|}
\hline \multirow[b]{3}{*}{$\begin{array}{l}\text { Building } \\
\text { Prototype }\end{array}$} & \multirow[b]{3}{*}{ Location } & \multicolumn{4}{|c|}{ Energy Use Intensity } & \multirow{2}{*}{\multicolumn{2}{|c|}{$\begin{array}{c}\text { Savings } \\
90.1-2007 \text { vs. } \\
\text { IECC2003 }\end{array}$}} \\
\hline & & \multicolumn{2}{|c|}{ IECC2003 } & \multicolumn{2}{|c|}{ 90.1-2007 } & & \\
\hline & & $\begin{array}{c}\text { Electricity } \\
(\mathrm{kWh} / \mathrm{sf} / \mathrm{yr})\end{array}$ & $\begin{array}{c}\text { Natural } \\
\text { Gas } \\
(\mathrm{kBtu} / \mathrm{sf} / \mathrm{yr})\end{array}$ & $\begin{array}{c}\text { Electricity } \\
(\mathrm{kWh} / \mathrm{sf} / \mathrm{yr})\end{array}$ & $\begin{array}{c}\text { Natural } \\
\text { Gas } \\
(\mathrm{kBtu} / \mathrm{sf} / \mathrm{yr})\end{array}$ & Energy & Cost \\
\hline Nonresidential & $\begin{array}{c}\text { New York } \\
\text { City }\end{array}$ & 12.32 & 5.42 & 11.85 & 4.76 & $4.8 \%$ & $4.3 \%$ \\
\hline Residential & $\begin{array}{c}\text { New York } \\
\text { City }\end{array}$ & 9.05 & 17.04 & 8.90 & 13.89 & $7.7 \%$ & $5.0 \%$ \\
\hline Semiheated & $\begin{array}{c}\text { New York } \\
\text { City }\end{array}$ & 4.37 & 16.53 & 4.37 & 16.39 & $0.5 \%$ & $0.3 \%$ \\
\hline Nonresidential & Albany & 12.21 & 7.57 & 11.79 & 6.38 & $5.4 \%$ & $4.4 \%$ \\
\hline Residential & Albany & 8.89 & 21.46 & 8.85 & 18.92 & $5.2 \%$ & $3.2 \%$ \\
\hline Semiheated & Albany & 4.34 & 21.38 & 4.33 & 21.27 & $0.4 \%$ & $0.3 \%$ \\
\hline Nonresidential & Binghamton & 12.09 & 7.90 & 11.65 & 6.62 & $5.7 \%$ & $4.7 \%$ \\
\hline Residential & Binghamton & 8.93 & 22.94 & 8.88 & 20.44 & $4.9 \%$ & $3.1 \%$ \\
\hline Semiheated & Binghamton & 4.40 & 24.64 & 4.39 & 24.51 & $0.3 \%$ & $0.2 \%$ \\
\hline
\end{tabular}

\section{Cost Effectiveness Analysis}

New York State has a requirement for a ten-year simple payback for new code requirements. At the request of New York, BECP examined the cost effectiveness of Standard 90.1-2007 compared to the NYSECC based on the changes identified for the three building prototypes covered in this analysis. The analysis approach used was a comparison of incremental cost to build the three prototype buildings compared to the incremental savings that would be achieved using Standard 90.1-2007.

The only significant changes identified in these three prototypes were related to envelope measures. Roof insulation, wall insulation, slab insulation, and window performance requirements differed as noted in Table 1.

The envelope requirements generation spreadsheet used by the ASHRAE SSPC 90.1 envelope subcommittee to generate the requirements for Standards 90.1-2004, 2007, and proposed requirements for 90.1-2010 was used. Specifically, the latest available cost information taken from the "2010 Opaque Constr" tab and the "FenestrationData 2010" tab of the" 901EnvOpt_VBA(2009-01-24).xls” spreadsheet was used to generate costs for this analysis. Where opaque constructions identified in the 2003 IECC were not explicitly identified in the tables in this spreadsheet, value were interpolated to provide cost estimates for opaque constructions. For glazing performance, the lowest cost option for meeting the requirements of 
either Standard 90.1-2007 or the 2003 IECC was identified, even if that option might provide better performance than was required to meet the code requirements. (For example, a low cost metal framed, double paned low-e argon filled window with a U-factor of 0.47 and an SHGC of 0.24 was used as the cost basis for windows that need to meet U/SHGC requirements of $0.50 / .40$, $0.48 / .40$, and $0.47 / .40$ because this window was clearly the lowest cost option in this range.) $\mathrm{A}$ first cost adjustment factor of 1.2 for New York City (Zone 4A) was used at the suggestion of Mark Eggers of NYSERDA. Estimated first cost impacts are shown in Table 3 for each building prototype in each climate zone. First cost impacts range from $\$ 0$ for semiheated warehouses to a high of \$34,530 for the nonresidential office building in New York City.

Table 3: New York State Calculated Incremental First Cost Impacts

\begin{tabular}{|l|l|l|l|}
\hline Building Prototype & $\begin{array}{l}\text { Climate Zone 4A - } \\
\text { New York City }\end{array}$ & $\begin{array}{l}\text { Climate Zone 5A - } \\
\text { Albany }\end{array}$ & $\begin{array}{l}\text { Climate Zone 6A - } \\
\text { Binghamton }\end{array}$ \\
\hline Nonresidential & $\$ 34,530$ & $\$ 17,773$ & $\$ 18,142$ \\
\hline Residential & $\$ 21,083$ & $\$ 10,423$ & $\$ 9,525$ \\
\hline Semiheated & $\$ 0$ & $\$ 0$ & $\$ 0$ \\
\hline
\end{tabular}

Gas and electricity savings were taken directly from the analysis spreadsheets that led to Table 2. The values of the savings may be derived by taking the difference in energy use intensity values for gas and electricity in Table 2 and multiplying the difference by the square footage of the building. Estimated energy cost savings are shown in Table 4 for each building prototype in each climate zone. Energy cost savings range from a low of around $\$ 100$ for semiheated warehouses to a high of \$4,597 for the nonresidential office building in Binghamton.

Table 4: New York State Calculated Incremental Energy Cost Savings

\begin{tabular}{|l|l|l|l|}
\hline Building Prototype & $\begin{array}{l}\text { Climate Zone 4A - } \\
\text { New York City }\end{array}$ & $\begin{array}{l}\text { Climate Zone 5A - } \\
\text { Albany }\end{array}$ & $\begin{array}{l}\text { Climate Zone 6A - } \\
\text { Binghamton }\end{array}$ \\
\hline Nonresidential & $\$ 4,464$ & $\$ 4,349$ & $\$ 4,597$ \\
\hline Residential & $\$ 2,050$ & $\$ 1,234$ & $\$ 1,185$ \\
\hline Semiheated & $\$ 94$ & $\$ 115$ & $\$ 89$ \\
\hline
\end{tabular}

The resulting kWh/yr and kBtu/yr values were then multiplied by the New York State Fuel Costs for 2007 taken from http://www.nyserda.org/energy_information/energy_prices_supplies.asp. No adjustment for fuel costs in 2008 was made. No adjustment for increased fuel costs in New York City was made. The resulting payback periods calculated in this analysis are shown in Table 5. 
Table 5: New York State Calculated Paybacks

\begin{tabular}{|l|l|l|l|}
\hline Building Prototype & $\begin{array}{l}\text { Climate Zone 4A- } \\
\text { New York City }\end{array}$ & $\begin{array}{l}\text { Climate Zone 5A - } \\
\text { Albany }\end{array}$ & $\begin{array}{l}\text { Climate Zone 6A - } \\
\text { Binghamton }\end{array}$ \\
\hline Nonresidential & 8 & 4 & 4 \\
\hline Residential & 10 & 8 & 8 \\
\hline Semiheated & 0 (no change) & 0 (no change) & 0 (no change) \\
\hline
\end{tabular}

Note - the values above are rounded to the nearest integer values for clarity

This analysis indicates that the adoption of Standard 90.1-2007 is, on average, cost-effective under New York's requirements for buildings in New York State. The requirement in the New York State Energy Law (Energy Law Article 11-103.2) is that the overall code update be cost effective on average for the state. The average value for the code would depend on the weighting factors provided for each prototype, but the average is clearly between 0 and 10 , as shown in Table 5. 


\section{Appendix A - Prototype Building Descriptions}

Table A-1: Nonresidential Prototype Building Characteristics

\begin{tabular}{|c|c|}
\hline Characteristic & Prototype Building Model Description \\
\hline \multicolumn{2}{|l|}{ GENERAL } \\
\hline Building Type & Medium Office \\
\hline Gross Floor Area & $53,600 \mathrm{ft}^{2}$ \\
\hline Building Shape & Rectangle \\
\hline Aspect Ratio & $1.5(164 \mathrm{ft} \times 109 \mathrm{ft})$ \\
\hline Number of Floors & 3 \\
\hline Window to Wall Ratio & 33\% (modeled as strip windows of $5 \mathrm{ft}$. high) \\
\hline Floor Height & $13 \mathrm{ft}$ \\
\hline Floor-to-Ceiling Height & $9 \mathrm{ft}$ \\
\hline Exterior Wall & Steel-framed wall \\
\hline Roof & Insulation entirely above deck, metal deck roof \\
\hline Floor & 8” Slab-on-grade \\
\hline \multicolumn{2}{|l|}{ INTERNAL LOADS } \\
\hline \multicolumn{2}{|l|}{\begin{tabular}{l|l} 
Occupancy \\
\end{tabular}} \\
\hline Number of People & 5 persons / 1000 sf \\
\hline \multicolumn{2}{|l|}{ Lighting } \\
\hline Power Density & $1.0 \mathrm{w} / \mathrm{sf}$ \\
\hline \multicolumn{2}{|l|}{ Plug Load } \\
\hline \begin{tabular}{|l|l|} 
& Average Power Density \\
\end{tabular} & $0.75 \mathrm{w} / \mathrm{sf}$ \\
\hline \multicolumn{2}{|l|}{ HVAC } \\
\hline \begin{tabular}{|l|l} 
Heating Type \\
\end{tabular} & Gas furnace \\
\hline Cooling Type & Packaged DX Unit \\
\hline Fan Control & Variable air volume \\
\hline Distribution/Terminal Units & VAV terminal box with electric reheating coil \\
\hline Cooling T-stat & $75^{\circ} \mathrm{F}\left(80^{\circ} \mathrm{F}\right.$ setback) \\
\hline \begin{tabular}{l|l} 
Heating T-stat \\
\end{tabular} & $70^{\circ} \mathrm{F}\left(60^{\circ} \mathrm{F}\right.$ setback $)$ \\
\hline \multicolumn{2}{|l|}{ SERVICE WATER HEATER } \\
\hline \begin{tabular}{|l|} 
Water Heater Type \\
\end{tabular} & Electric storage water heater \\
\hline Tank Capacity, gallon & 260 \\
\hline Supply Temperature, ${ }^{\circ} \mathrm{F}$ & 120 \\
\hline
\end{tabular}


Table A-2: Residential Prototype Building Characteristics

\begin{tabular}{|c|c|}
\hline Characteristic & Prototype Building Model Description \\
\hline \multicolumn{2}{|l|}{ GENERAL } \\
\hline Building Type & Multi-family residential building \\
\hline Gross Floor Area & $33,700 \mathrm{ft}^{2}$ \\
\hline Building Shape & Rectangle \\
\hline Aspect Ratio & 2.75 (152 ft x 56 ft) \\
\hline Number of Floors & 4 \\
\hline Activity Area & $\begin{array}{l}\text { Each floor has } 8 \text { (25’x38') apartments, except ground } \\
\text { floor which has } 7 \text { apartments and one lobby/office }\end{array}$ \\
\hline Window to Wall Ratio & 15\% (4ft high view windows) \\
\hline Floor Height & $10 \mathrm{ft}$ \\
\hline Floor-to-Ceiling Height & $10 \mathrm{ft}$ (for the office area only) \\
\hline Exterior Wall & Steel-framed wall \\
\hline Roof & Insulation entirely above deck, metal deck roof \\
\hline \begin{tabular}{l|l} 
Floor \\
\end{tabular} & 8” Slab-on-grade \\
\hline \multicolumn{2}{|l|}{ INTERNAL LOADS } \\
\hline \multicolumn{2}{|l|}{ Occupancy } \\
\hline Number of People & 78 persons total (average 2.5 persons per apartment unit) \\
\hline \multicolumn{2}{|l|}{ Lighting } \\
\hline Average Power Density & $\begin{array}{lll}\text { - } & \text { Apartment units: } 0.36 \mathrm{w} / \mathrm{sf} \\
\text { - } & \text { Corridors: } & 0.5 \mathrm{w} / \mathrm{sf} \\
\text { - } & \text { Office area: } & 1.1 \mathrm{w} / \mathrm{sf} \\
\end{array}$ \\
\hline \multicolumn{2}{|l|}{ Plug Load } \\
\hline Average Power Density & $0.62 \mathrm{w} / \mathrm{sf}$ \\
\hline \multicolumn{2}{|l|}{ HVAC } \\
\hline Heating Type & Gas furnace \\
\hline Cooling Type & Split system DX (one per apartment) \\
\hline Fan Control & Constant volume \\
\hline Distribution/Terminal Units & Single zone/Direct air \\
\hline Cooling T-stat & $75^{\circ} \mathrm{F}$ (no setback assumed) \\
\hline \begin{tabular}{|l|l|} 
Heating T-stat \\
\end{tabular} & $70^{\circ} \mathrm{F}$ (no setback assumed) \\
\hline \multicolumn{2}{|l|}{ SERVICE WATER HEATER } \\
\hline Water Heater Type & Individual residential electric storage water heater \\
\hline Tank Capacity, gallon & 20 (per apartment unit) \\
\hline Supply Temperature, ${ }^{\circ} \mathrm{F}$ & 120 \\
\hline
\end{tabular}


Table A-3: Semiheated Prototype Building Characteristics

\begin{tabular}{|c|c|}
\hline Characteristic & Prototype Building Model Description \\
\hline \multicolumn{2}{|l|}{ GENERAL } \\
\hline \begin{tabular}{|l|l|} 
& Building Type \\
\end{tabular} & Non-refrigerated warehouse \\
\hline Gross Floor Area & $49,500 \mathrm{ft}^{2}$ \\
\hline Building Shape & Wide rectangle \\
\hline Aspect Ratio & $2.2(330 \mathrm{ft} \times 150 \mathrm{ft})$ \\
\hline Number of Floors & 1 \\
\hline $\begin{array}{l}\text { Activity Area } \\
\text { (percentage of gross floor } \\
\text { area) }\end{array}$ & $\begin{array}{ll}\text { - } & \text { Bulk storage area: } 34,500 \mathrm{ft}^{2}(70 \%) \\
\text { - } & \text { Fine storage area: } 12,450 \mathrm{ft}^{2}(25 \%) \\
\text { - } & \text { Office area: } 2,550 \mathrm{ft}^{2}(5 \%)\end{array}$ \\
\hline Window to Wall Ratio & $\begin{array}{l}\text { - Storage area: no windows } \\
\text { - Office area: } 12 \% \text { view windows }\end{array}$ \\
\hline Floor Height & $28 \mathrm{ft}$ \\
\hline Floor-to-Ceiling Height & $14 \mathrm{ft}$ (for the office area only) \\
\hline Exterior Wall & Metal building wall \\
\hline Roof & Metal building roof \\
\hline Floor & 6” Slab-on-grade \\
\hline \begin{tabular}{|l|l|} 
& Door \\
\end{tabular} & 7 opaque doors (3'x7'), 7 roll-up dock doors (8'x10') \\
\hline \multicolumn{2}{|l|}{ INTERNAL LOADS } \\
\hline \multicolumn{2}{|l|}{\begin{tabular}{|l|} 
Occupancy \\
\end{tabular}} \\
\hline Number of People & 5 (in the office area) \\
\hline \multicolumn{2}{|l|}{ Lighting } \\
\hline Average Power Density & $\begin{array}{ll}\text { - } & \text { Bulk storage area: } 0.8 \mathrm{w} / \mathrm{sf} \\
\text { - Fine storage area: } 0.8 \mathrm{w} / \mathrm{sf} \\
\text { - Office area: } \quad 1.0 \mathrm{w} / \mathrm{sf} \\
\end{array}$ \\
\hline \multicolumn{2}{|l|}{ Plug Load } \\
\hline Average Power Density & $\begin{array}{l}\text { Office: } 0.75 \mathrm{w} / \mathrm{sf} \\
\text { Bulk storage: } 0.24 \mathrm{w} / \mathrm{sf}\end{array}$ \\
\hline \multicolumn{2}{|l|}{ HVAC } \\
\hline \begin{tabular}{|l|l|} 
& Heating Type
\end{tabular} & $\begin{array}{ll}\text { - } & \text { Bulk storage area: unit heater } \\
\text { - } & \text { Fine storage area: Gas furnace } \\
\text { - } & \text { Office area: Gas furnace } \\
\end{array}$ \\
\hline Cooling Type & $\begin{array}{ll}\text { - } & \text { Bulk storage area: no cooling } \\
\text { - } & \text { Fine storage area: Direct expansion } \\
\text { - } & \text { Office area: Direct expansion }\end{array}$ \\
\hline Fan Control & Constant volume \\
\hline Distribution/Terminal Units & Single zone/Direct air \\
\hline Cooling T-stat & $\begin{array}{ll}\text { - } & \text { Fine storage area: } 80^{\circ} \mathrm{F} \\
\text { - } & \text { Office area: } 75^{\circ} \mathrm{F}\left(85^{\circ} \mathrm{F} \text { setback }\right) \\
\end{array}$ \\
\hline Heating T-stat & $\begin{array}{ll}\text { - } & \text { Bulk storage area: } 50^{\circ} \mathrm{F} \\
\text { - } & \text { Fine storage area: } 60^{\circ} \mathrm{F} \\
& \text { Office area: } 70^{\circ} \mathrm{F}\left(60^{\circ} \mathrm{F} \text { setback }\right) \\
\end{array}$ \\
\hline \multicolumn{2}{|l|}{ SERVICE WATER HEATER } \\
\hline \begin{tabular}{|l|} 
Water Heater Type \\
\end{tabular} & Electric storage water heater \\
\hline Tank Capacity, gallon & 20 \\
\hline Supply Temperature, ${ }^{\circ} \mathrm{F}$ & 120 \\
\hline
\end{tabular}

